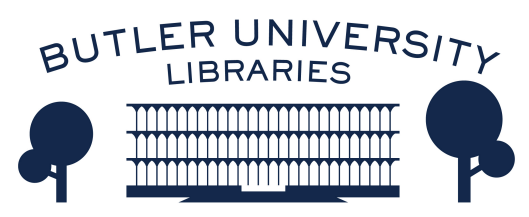

Journal of Hindu-Christian Studies

Volume 16

Article 5

January 2003

\title{
Hindu-Christian Dialogue: Revisiting the Tannirpalli Trinitys \\ Original Vision
}

Klaus Klostermaier

Follow this and additional works at: https://digitalcommons.butler.edu/jhcs

Part of the Religion Commons

\section{Recommended Citation}

Klostermaier, Klaus (2003) "Hindu-Christian Dialogue: Revisiting the Tannirpalli Trinitys Original Vision," Journal of Hindu-Christian Studies: Vol. 16, Article 5.

Available at: https://doi.org/10.7825/2164-6279.1294

The Journal of Hindu-Christian Studies is a publication of the Society for Hindu-Christian Studies. The digital version is made available by Digital Commons @ Butler University. For questions about the Journal or the Society, please contact cbauman@butler.edu. For more information about Digital Commons @ Butler University, please contact digitalscholarship@butler.edu. 


\title{
HINDU-CHRISTIAN DIALOGUE: REVISITING THE TANNIRPALLI TRINITYS ORIGINAL VISION
}

\author{
Klaus Klostermaier \\ University of Manitoba
}

\begin{abstract}
LIVING in India from 1961 to 1970 I intensively and extensively participated in Hindu-Christian Dialogue at various levels, academic as well as existential, and I came to know personally most of the then leading figures. While Hindu friends even then kept regularly imploring their Christian counterparts to persuade their churches to desist from proselytizing, they welcomed and encouraged dialogue. During the last decades the relationship between Hindus and Christians in India has visibly deteriorated. In the context of legislation increasingly restricting or forbidding Christian missionary activities, also dialogue efforts have come under suspicion as being "mission by another "method." Pronouncements by past and present presidents of the Vatican Secretariat for Non-Christians (and its successor) ${ }^{1}$ and utterances such as those of Pope John-Paul II during his last visit to India, when he publicly expressed his hope that "in the third
\end{abstract}

Christian millennium a great harvest of faith will be reaped in this vast and vital continent" are apt to feed such suspicions. Hindus also noted with disdain the Southern Baptists' recent prayer call for the "more than 900 million people lost in the hopeless darkness of Hinduism" and their ambitious plans to bring their own light to them. Last month's Vatican announcement that Mother Teresa of Kolkata will be beatified in Rome on Mission Sunday (!) later this year, was immediately picked up by Hindus as proof for the "ulterior motives" in her humanitarian work. Incidents like these severely strain Hindu-Christian relations and harm genuine Hindu-Christian dialogue.

Sita Ram Goel, once a supporter of Hindu-Christian dialogue, accused in his widely read book Catholic Ashrams: Samnyasins or Swindlers?" the "Tannirpalli Trinity" [Father Jules Monchanin ("Swami Parama Arubi Ananda"), Dom Henry le Saux ("Swami Abhishiktesvarananda") and

Klaus Klostermaier is University Distinguished Professor Emeritus, University of Manitoba, Winnipeg, Canada, where he has been teaching since 1970. His voluminous writings include Hindu and Christian in Vrindaban, SCM 1970 (U.S. edition In the Paradise of Krsna, Westminster 1971), re-issued by Trinity-Press 1993; A Survey of Hinduism, SUNY Press, 2nd ed. 1994. His most recent publications, all with Oneworld, Oxford, are: A Concise Encyclopedia of Hinduism (1998), Hinduism: A Short History (1999), Buddhism: A Short Introduction (1999), Hinduism: A Short Introduction (2000); The Wisdom of Hinduism (2000), Hindu Writings (2001). His main interest is India: specifically Indian religions, including inter-religious dialogue, but also questions relating to the socio-political and the economic-cultural situation of present day India. At present he is completing a number of long and short articles for several major encyclopedias. His major current research is devoted to Hindu-Muslim relations in India in the last 100 years. 
Dom Bede Griffiths] of not seeking genuine dialogue but selling "Old Merchandise in a New Package," i.e. being disguised missionaries, implicitly accusing all involved in the Christian Ashram-movement in India of being swindlers rather than genuine samnyasins. ${ }^{3}$

Jules Monchanin I have never met: he had died four years before I came to India. From what I have heard from those who had known him, and from what I have read in his own writings and about him, he must have been an extraordinary person with enormous charm and personal magnetism, besides possessing outstanding intellectual gifts and unusual erudition.

For over a decade I had been quite close to Dom Henri Le Saux, or "Abhishikt," as we used to call him. Meeting him soon after my arrival in India in early 1962, invited to a gathering of the "Cuttat-Group," and later at other occasions, especially at Murray Rogers' Jyotiniketan Ashram, I also spent some time with him at Santivanam, and he visited me when I was living in Vrindaban and later in Bombay, where he entrusted me with the publication of his Hindu-Christian Meeting Point: Within the Cave of the Heart. $^{4}$ I have kept a fair number of his letters, which he sent me after I had moved to Canada - the last one written not long before his death.

Dom Bede Griffiths I also met with the Cuttat Group and at other dialogue conferences in India. I considered it an honour and an expression of his trust that he asked me at some time to write an article on Hindu-Christian Dialogue for the Journal of Ecumenical Studies on his behalf. ${ }^{5}$

I was in sympathy with the ideal these men tried to realize and felt personally much attracted to their vision. ${ }^{6}$ I preserve a photograph in my files with Abhishikt, Bede Griffiths, Fr. Hendrecourt, and myself in Moussouri, on the way from the Rajpur Cuttat-Group meeting to the 1962 Kumbha Mela in Rishikesh and Hardwar. I was new to India then, and new to the dialogue group for whom I had immense respect. I listened interestedly to their discussions about the appropriateness of a Christian visiting a Hindu temple. The three "experts" did not think it an issue to be taken lightly. Later on, living in Vrindaban, when it had become a matter of almost daily routine for me to make the rounds of temples and to participate in satsangs and all manner of Hindu celebrations, I sometimes recalled this memorable debate with some wondering.

Their writings and their biographies clearly show that each of the three men later associated with Saccidananda Ashram followed a very special personal vocation - a religious calling thoroughly tested both before coming to India and after. All three had read extensively about India in their home countries and they knew a great deal about Indian culture and religion, though none of them had acquired academic degrees in Indian studies or great proficiency in Indian languages. They believed to be responding to Christ's command to "make disciples of all nations" (Mt 28, 16) - a scriptural injunction, whose authenticity they were not questioning (as contemporary New Testament scholars do). Monchanin, a member of the secular clergy of the Archdiocese of Lyons, joined Fr. Lebbe's "Auxiliaires missionaires" to serve under Bishop Mendonca of Tiruchirapalli. Le Saux, a Benedictine monk in a French abbey, encouraged by a visiting Indian priest, came to India with the intent of establishing an Indian Benedictine monastery, eventually founding with Monchanin the Saccidanda Ashram. Griffiths, originally an Anglican, joined Fr. Francis Mahieu's Kurisumala Ashram, a Christian monastic establishment in Kerala following the Syrian rite. They also believed that by following their Christian calling they joined the Hindu samnyasins in their pilgrimage in search of the Absolute. ${ }^{7}$

They were inspired by Roberto de Nobili and Brahmabhandab Upadhyaya, to whom they referred quite explicitly in their writings ${ }^{8}$, and they were hoping that by 
following more traditional Indian ways of life and by incorporating elements of Hindu worship in the Eucharist they would make the local Roman Catholic Church more "Indian": a move criticised by more conservative Indian Christians. Goel, detailing some of the more fraudulent conversion practices of de Nobili, seems to imply that the Tannirpalli Trinity's admiration for the man made them coconspirators against Hinduism: swindlers rather than genuine samnyasins. The Tannirpalli Trinity, however, did not adopt de Nobili's missionary methods: they were sincere in their self-denial, honest in their scholarly work, open in everything that concerned their lives, not out to deceive anyone. They certainly were not swindlers. But were they samnyasins?

They had renounced family and possessions, they lived simple and frugal lives, they spent most of their time in study, prayer and meditation. Many Hindus, for whatever personal reasons, don the ochre robe on their own and enjoy free food and lodging at the kshetras. Samnyasa, however, as an important Hindu institution, has definite rules and regulations. While no longer bound to observe the general caste regulations, samnyasins have to follow the yati-dharma. ${ }^{9}$ In order to qualify as a genuine samnyasin one has to receive diksha by a recognized guru after having gone through the required preparation. Diksha has specific prerequisites and entails its own obligations. While Hinduism may not be as narrowly (institutionally and dogmatically) defined a "religion" as Roman Catholicism, it is not as amorphous and nondescript as Bede Griffiths seems to assume in his exchange of letters with Swami Devananda. ${ }^{10}$ In order to be a genuine samnyasin, one must belong to one of the recognized sampradayas whose members have to submit on matters of life-style and teaching to their respective leaders. If the authorities of Christian monastic communities claim exclusive legitimacy to determine conditions of membership, it cannot be left to non-Hindus to decide who is a samnyasin. One, who acknowledges the intrinsic spiritual value of Hindu samnyasa, must also be ready to submit as a shishya to a genuine Hindu guru. Someone who is not prepared to do this is also not entitled to use the external paraphernalia of samnyasa. Wearers of the ochre robe for centuries have earned the respect of the Hindu people by following Hindu traditions - it would be dishonest to gain materially or morally from this deposit of faith without participating fully in that tradition..

The Tannirpalli Trinity did not become part of the traditional Hindu samnyasin milieu nor did they become associated with a particular Hindu teaching tradition. ${ }^{11}$ Neither Monchanin nor Griffiths cultivated sustained relations with traditional Hindu mathas. Abhishiktananda visited the Ramana Maharshi Ashram in Annamalai for a few weeks (after Ramana Maharsi's departure), spent some time in one of the nearby caves of Arunacala and also stayed for some time with Swami Cidananda in the Sivananda Ashram in Rishikesh. Both are modern, non-traditional outfits, geared towards a liberal clientele, including foreigners. Abhishiktananda may well have had a profound inner experience on Arunacala about which he writes with great eloquence - but that did not make him an initiated samnyasin in any Hindu sampradaya. In Uttarkashi, in his own kutiya, Swami Abhishiktananda lived very much for and by himself (except for the short time when Marc, his French disciple, was with him) - often observing maunasadhana, and not socialising in any significant way with the local sadhu community. ${ }^{12}$

Besides their illegitimate use of the samnyasin garb, what Goel found particularly infuriating was their superimposition of the sacred Hindu pranava (OM) on the Christian cross: it appeared over the entrance to the chapel of Saccidanda Ashram and on the necklaces of the Tannirpalli Trinity. "Nailing the Om to 
the Cross" he perceives as one of the worst sins against the Hindu spirit. Hindus anyhow usually react negatively to the image of Christ nailed to the cross - to "crucify the OM" they consider an unpardonable misuse of their most sacred symbol. Strange, that the Tannirpalli Trinity were not sensitive enough to see this point. They obviously believed to be free to take over from Hindu culture whatever they could fit into Christianity, as they understood it, referring frequently to the way the early Church Fathers had Christianised neo-Hellenic culture. Classical Greek culture, however, was dying out at that time and the Roman Empire had become Christian, when theologians began assuming its legacy. After Christianity had become the state religion of the Roman Empire, the Church could deal with paganism however it pleased - and it did so quite ruthlessly. It not only appropriated all pagan temple property but also exploited pagan literature and philosophy for Christian purposes. Church writers referred to the precedent of the Israelites who claimed the golden vessels they had stolen from Egyptian temples as gifts from their own God. Christian theologians likewise asserted that whatever good and true was found in Greek philosophy belonged to Christians as rightful inheritors of the Kingdom. ${ }^{13}$

The Indian situation is quite different: Indian traditions, ancient as they may be, are still alive and flourishing, and their custodians are not willing to surrender them freely. The recent colonial past has sharpened the pride of Hindus in their own traditions, and the Hindu jagaran that began a century ago, has lead to an invigoration of Hindu culture in many areas. Hindus resent the appropriation of their culture for alien purposes, as they resent the interpretation of their tradition from alien and often distorting perspectives. ${ }^{14}$

The main objection of Hindus to Christian missions was that it was out to destroy Hindu culture and to "denationalize" the converts. During Muslim. rule and later during the British Raj the Hindus had to tolerate massive abuse of their religion and their customs - they are no longer willing to accept this. The Tannnirpalli Trinity did not engage in missionary activities, they did not "denationalize" any Hindus - nor did they seek planned dialogues with Hindus. At the time of Monchanin the very notion of "dialogue" had not yet become part of the Church vocabulary. ${ }^{15}$ Abhishikt, while participating in some meetings of Christians talking about dialogue - practicing, what Jacque Albert Cuttat had called "inner dialogue" - did not engage in dialogue with Hindus other than with those few who by chance personally befriended him. ${ }^{16}$ One reason for this was probably linguistic: his English remained strongly accented, his Hindi was virtually non-existing, his Tamil probably not good enough for serious inter-religious dialogue. He was communicating more often through gestures than through words. He also believed that the time was not yet ripe for "outer" dialogue. It was not deviousness but real conviction that made him not only decline an invitation to participate in a dialogue meeting at Ajaltoun (Lebanon) in March 1970, organised by Stanley Samartha under the auspices of the World Council of Churches, at which some notable Hindu scholars were present, but also to write under the pseudonym Sivendra Prakash a letter: "Dialogue Postponed," in which he laid out the standard Hindu objections against Christian missions and dialogue. Murray Rogers, the recipient of the letter, read it out together with his own comments at the meeting - nobody else knew at that time who the real author was. 17 The letter not only shows that Abhishikt was familiar with the Hindu arguments against dialogue, but also suggests that he had made them largely his own. ${ }^{18}$

Bede Griffiths' "English only" restricted his contacts to English speaking Indians, among them also some Hindu students, with whom he established friendships. Saccidananda Ashram became under his 
guidance mainly a retreat for individual Western educated Hindus and Western Christians who looked for quiet and spirituality and who found his idea of a "Marriage of East and West" attractive.

Monchanin, by establishing Saccidanda Ashram, hoped to create the outward conditions to realize "the essential vocation of the Church and of India,"19 the contemplation of the (Trinitarian) mystery of God: "Contemplation stands supreme; viewed either from the standpoint of God, or from that of man, or from that of the Holy Church. God has created the Universe for His own glory, and out of love, in order to diffuse His intrinsic goodness and to make intelligent creatures sharers in His eternal bliss." He pursued this Platonic ideal ${ }^{20}$ in a Christian spirit - and assumed it to be identical with the spiritual thrust of Hindu samnaysa ${ }^{21}$. He held that the contemplation of the Trinitarian God was the fulfilment not only of his own Christian (priestly) vocation but also the realization of the true meaning of life for all human beings, and that in reaching out for it, he met the soul of India.

In their co-authored work "An Indian Benedictine Ashram," Monchanin and Le Saux expressed the opinion that "India is to Asia what Greece was to Europe" and that "the Christianisation of Indian civilisation is to all intents and purposes an historical undertaking comparable to the Christianisation of Greece." Possibly prompted by an ecclesiastical censor, they added to the compliment that "India has received from the almighty an uncommon gift, an unquenchable thirst for whatever is spiritual," the qualification that "Indian wisdom is tainted with erroneous tendencies", and that "Man outside the unique Revelation and the unique Church is always unable to sift truth from falsehood, good from evil." Apart from finding it difficult today to accept notions like "the unique -Revelation" and "the unique Church," history (also the most recent) has amply proven that also "Man inside' the unique Revelation and the unique Church" has frequently been unable "to sift truth from falsehood and good from evil." This is not the place to detail the sins of the fathers suffice it to remind of the numerous declarations of apology, which the present Pope felt constrained to make for crimes committed by, and in the name of "the unique Church." In Hindu-Christian dialogue the assumption of such uncalled for uniqueness would prove fatal - it has its parallel in a similar Hindu claim, which is equally unjustified.

Abhishiktananda, after having lived in India for many years and having moved outside the Saccidananda Ashram, became more aware of the differences between the original Christian-Platonic vision and Hindu spirituality, but never moved far enough intellectually into Hindu territory to gain citizenship there. $\mathrm{He}$ built his (Christian) theology on an eclectic and idiosyncratic interpretation of the Upanishads and although calling it Advaita, he did not connect with any orthodox Hindu darshana. While taking over selectively some Hindu practices, he did not follow in his sadhana the routine of any recognized Hindu sampradaya. He did, however, make some inroads in the Catholic Church. Some of the younger Indian clergy, who had grown up in Independent India and who shared the nationalism of their fellow Indians, began to see the need for Indianising Christianity not only administratively but also theologically. In the latter period of his life, especially after the 1969 Bangalore Seminar "The Church in India", Abhishikt was invited to address priests and nuns on prayer and meditation with an Indian background. Abroad, his writings became fairly well known in some Christian circles, especially in France. After his death some of his friends founded the Abhishiktananada Society, publishing a nonperiodical Bulletin "Setu."

Bede Griffiths, for many years involved with Kurisumala, a Syrian rite Christian monastery in Kerala, left it largely because he did not share the more practical 
agricultural development interests of Fr. Mahieu and took over Santivanam from Abhishiktananda, where he had more freedom to live out his own ideas, which were closer to the contemplative ideal of Monchanin. He sought affiliation with the Trappist monastery of Camaldoli (Italy), thus identifying himself with the Western Christian monastic tradition rather than with any Hindu sampradaya. In his polemic exchanges with Swami Devananda he repeatedly (and unnecessarily) referred to the Catholic Church hierarchy's approval of his way of life. He too found more resonance among Christians in the West than among Hindus in India. ${ }^{22}$

When multinational pharmaceutical concerns began patenting Indian indigenous medicinal plants for commercial exploitation, demands were voiced to protect India's natural and cultural heritage for the benefit of the people of India. This has relevance also for the Hindu religious heritage. Hindus object to subsuming their symbols and traditions under some alien label. Some Hindus, well read in Christian theology, traditional as well as contemporary, have begun to submit Christianity to a substantial critique..$^{23}$ Christian theologians, not only in India, will have to answer searching questions from Hindus, who find Christian teachings unconvincing and Christian practices, past and present, often unacceptably "unChristian". Old issues like the devastation of the Americas by some of the most Christian nations of Europe and the way the Portuguese treated Hindus in their Indian territories are being raised again. Hindus are not convinced that a conversion from Hinduism to Christianity would benefit them or their country spiritually or otherwise.

India - and with it Hinduism - has undergone a dramatic change in the last two decades, affecting also the relationship between Hindus and followers of other religions. No longer are Hindus eager, as Sarvepalli Radhakrishnan had been, to present Hinduism as universal spirituality, utterly other-worldly, without organisation or dogma, accommodating virtually anything and everybody with a religious leaning. Hinduism is mutating from an open-air self-serve bazaar from which all could pick up whatever they liked and put it to whatever use, into an increasingly tightly controlled organisation that is establishing its own rules of business. Hindus have become self-conscious and have begun to define Hinduism in such a way as to exclude all religions that have not originated in India and that do not share the Indian cultural heritage. If Paul Hacker could in the 1960s describe Inclusivism as one of the characteristics of Hinduism, this is no longer true. There exist now powerful and influential Hindu organisations, which speak and act exclusively for large numbers of Hindus. Although not all Hindus may identify with the Vishva Hindu Parishad and its affiliates, it has the sympathies of many and acts world-wide as watchdog for Hindu interests, critically looking at everything that is spoken and written about Hinduism anywhere in the world, including the way Hinduism is being taught at American universities. ${ }^{24}$ It also has revived the Dharma-parishad of earlier ages, attempting a Hindu aggiornamento.

A dialogue with this new Hinduism will be different from the dialogue that had been attempted under Christian auspices in the past. $^{25}$ This time it is the Hindus who lay down the rules of the game. Indian Christians will have to establish a dialogue with this new Hinduism too, if only for the sake of survival. They are dealing now with Hindus who often know more about the history and reality of the Church than many Christians themselves. They will have to accept critique and instead of flaunting their difference in life-style and world-view - an attitude that earned them the doubtful distinction of a "Christian superiority complex" - they will have to demonstrate solidarity with their fellow Indians and largely re-appropriate the culture of their 
forefathers. When adopting Hindu religious practices and symbols they will have to follow Hindu conventions and get the Hindus' agreement, demonstrating respect for their spirit.

Few Christians and few Hindus will be interested in, and qualified for, interreligious dialogue on the level aimed at by the Tannirpalli Trinity. While na<ve perhaps in some ways, they rightly perceived an affinity between the spirituality of some Christian and Hindu traditions, a common desire for the Absolute. Establishing bridges not only through thinking and writing, but also through their own lives, they pioneered Hindu-Christian dialogue at the level of mysticism. While Hindus and Christians (like all other people) certainly need to have and to do many other things, it is this spirituality that keeps individuals and communities oriented towards the Centre. It alone gives meaning and depth to all other pursuits. In India, where religion still plays a vital role in private and public life, it is important for Hindus and Christians (and all others) to retain and regain a sense of its true spiritual meaning in the face of its misuse for all kinds of other purposes. If religions have a role to play in our world it is to keep alive that sense of the Presence, of the Mystery in this world of ours. All other things that organized religions traditionally did in the past have been taken up - and often more efficiently - by governments and other organisations, be it welfare or education. The Tannirpalli Trinity exemplified the spiritual dimension of existence, the unum necessarium, without which religion could not be distinguished from the rest of the world's business, entertainment and politics.

\section{Notes}

1. Cardinal Marella, the first President of the Secretariat, in a speech given at the Collegium Urbanum (published in the English version of the
Osservatore Romano December 19 , 1968) referred to most Roman Catholic scholars then active in India in HinduChristian dialogue - including Abhishiktananda, Bede Griffiths, and a Consultor of his own Secretariat - as "enemies of dialogue." Cardinal Arinze's, the present President 's language in "The Urgency of Dialogue with Non-Christians" (Origins 39/14) are no more reassuring.

2. Sita Ram Goel, Catholic Ashrams: Samnyasins or Swindlers? New Delhi: Voice of India, 1988. Second, enlarged edition: 1994, containing an exchange of open letters between Swami Devananda and Bede Griffiths 1987-89.

3. The "Ashram movement" as such had started earlier. Already Brahmabhandab Upadhyay had experimented with Ashram life and Bishop Winslow's Christa Prema Seva Ashram in Pune continues even today as an ecumenical venture.

4. English translation of $L a$ recontre de l'Hindouisme et du Christianisme, Bandra-Bombay 1969.

5. See my article, "HinduChristian Dialogue,"-Journal of Eccumenical Studies 5 (1968): 21-44.

6. See my "Samnyasa: A Christian Way of Life in Today's India?" which appeared in - amongst other places - Indian Ecclesiastical Studies (Bangalore) as lead-article of Vol. 7 (1968) 1, pp. 8-40

7. At one point I overheard Swami Abhishiktananda discussing the possibility of going naked, as many Hindu sadhus do, to 
express their complete renunciation of the world. Probably Church authorities would not have permitted that.

8. The memorial publication in honor of Fr. Monchanin carries on the frontispiece Brahmabhandab's "Hymn to the Trinity" (Vande Saccidanandam), which they also used in their liturgy.

9. There are texts like Yatidharmasangraha, ed. by V.M. Apte in the Anandashrama Series (No.60) that detail the duties of samnyasins in general; there are many additional regulations in the teachings of specific sampradayas.

10. Swami Devananda mentions in his letters that samnyasa diksa cannot be given to a non-Hindu. When in Italy he suggested to a Catholic Church dignitary that he would don the habit of a friar and preach Hinduism in the Italian countryside, he was informed that was against the law and he would be prosecuted if he attempted it.

11. There have been non-Indians, like Ronald Nixon (Krishna Prem), who underwent regular diksha and were accepted by Hindus as authentic samnyasins and temple priests.

12. Church authorities would probably not have approved their joining an authentic Hindu sampradaya.

13. Gregory of Nyssa, De Vita Moysis, 2, $11 \mathrm{ff}$

14. There is vocal Hindu opposition to the Freudian analysis of Hindu mythology widely practiced in U.S. academia.

15. Bede Griffiths, listening to two of Monchanin's public addresses, noticed a "sense of failure of communication, first with a largely Hindu, the second with a Catholic audience." See Swami Parama Arubi Anandam (Fr. J. Monchanin) 1895-1957. A Memorial, Saccidananda Ashram, 1959, 124.

16. When he visited me in Vrindaban, I introduced him to some of my Hindu friends. Dina Sharana Das, who had great respect and love for Christ, asked Abhishikt: What is your favorite Gospel passage? Abhishikt seemed perplexed by that question and mumbled something I could not understand. - Checking in his Spiritual Diary [as published by R. Panikkar] the entry under Vrindavan: May 5, 1963 [La montee au fond du coeur, Paris, O.E.I.L., 1986, p. 312 f] I found no reference at all to any encounter with Hindus in Vrindaban nor any comment on the place itself or his reaction.

17. Murray Rogers personally told me about that much later.

18. The letter, together with Roger Murray's comments, in S. J. Samartha (ed.) Dialogue Between Men of Living Faiths, WCC Geneva 1971, pp. 21-31.

19. Quotes from his writings as published in Swami Parama Arubi Anandam, pp. 159 ff.

20. Plotinus, Enneads V, 6 expresses the view that contemplation is the highest form of existence.

21. Swami Sivananda, Necessity for Samnyasa (Sivanandanagar: 2nd ed. 1963), "Instructions to Samnyasins," p. 75, No. 17: "You have no other duty to perform in this world than meditation 'on the Supreme Self or Brahman." 
22. Several good biographies of Bede Griffiths have appeared in English, the latest is J. B. Trapnell, Bede Griffiths: A Life in Dialogue, SUNY 2001.

23. Ashok V. Chowgule's Christianity in India: The Hindutva Perspective, Mumbai: Hindu Vivek Kendra, 1999 should also be read to learn how engaged Hindus view Christianity and Christian history.
24. Various websites submit the writings of American Hinduism scholars to critique from a Hindu standpoint.

25. In my essay "The Future of Hindu-Christian Dialogue" in $\mathrm{H}$. Coward (ed.), Hindu-Christian Dialogue: Perspectives and Encounters, Maryknoll, NY: Orbis Books, 1990, pp. 262274 , I expressed myself on this issue in greater length. 